\title{
Teaching NeuroImages: Spontaneous regression of AVM feeding pedicle pseudoaneurysms
}

Enrico Giordan, MD, * Lorenzo Rinaldo, MD, PhD, * and Giuseppe Lanzino, MD* Neurology ${ }^{\circledR}$ 2018;90:e1935-e1936. doi:10.1212/WNL.0000000000005565

\section{Correspondence}

Dr. Lanzino

Lanzino.giuspeppe@

mayo.edu

Figure Spontaneous resolution of distal feeder pseudoaneurysms
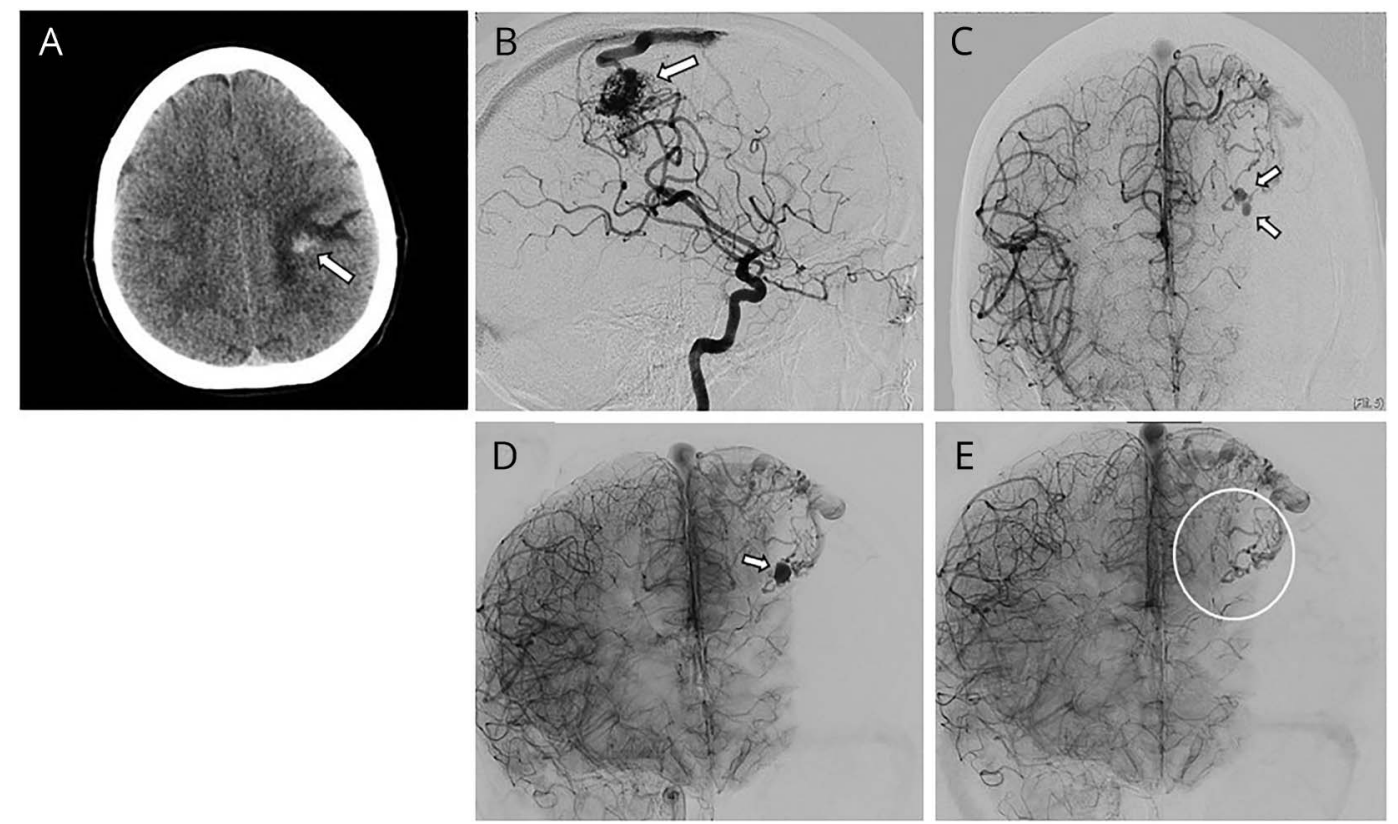

(A) Noncontrast CT shows frontal hemorrhage (arrow). (B) Angiography: left rolandic arteriovenous malformation. (C) Right-sided internal carotid injection: 2 feeding pedicle pseudoaneurysms (arrows). (D) Repeat angiography 2 months later revealed spontaneous obliteration of 1 of the 2 pseudoaneurysms but increase of the other (arrow). (E) One month later, angiography shows spontaneous resolution of the pseudoaneurysm (circle).

A 34-year-old woman had sudden left-sided weakness shortly after delivery. Head CT showed a small hemorrhage (figure, A) secondary to an arteriovenous malformation (figure, B) with 2 small pseudoaneurysms (figure, C). Angiography 2 months later documented obliteration of one of the 2 pseudoaneurysms but growth of the other (figure, D). Embolization of the pedicle bearing the pseudoaneurysm was planned but delayed by 1 month because of patient hesitation to undergo the procedure. Repeat angiogram showed spontaneous resolution (figure, E). Feeding pedicle pseudoaneurysms are dynamic lesions probably secondary to dissection. As remodeling occurs, interval growth, spontaneous regression, or both can be observed. ${ }^{1}$

\section{Author contributions}

Enrico Giordan: manuscript preparation, drafting manuscript, collection of data and figures, approval of final version. Rinaldo Lorenzo: manuscript preparation, drafting
MORE ONLINE

$\rightarrow$ Teaching slides:

links.lww.com/WNL/A478

*These authors contributed equally to this work.

From the Department of Neurosurgery, Mayo Clinic, Rochester, MN.

Go to Neurology.org/N for full disclosures. Funding information and disclosures deemed relevant by the authors, if any, are provided at the end of the article. 
manuscript, collection of data and figures, approval of final version. Giuseppe Lanzino: manuscript preparation, drafting manuscript, collection of data and figures, approval of final version.

\section{Study funding}

No targeted funding reported.

\section{Disclosure}

The authors report no disclosures relevant to the manuscript. Go to Neurology.org/N for full disclosures.

\section{Reference}

1. Rammos SK, Gardenghi B, Bortolotti C, Cloft HJ, Lanzino G. Aneurysms associated with brain arteriovenous malformations. AJNR Am J Neuroradiol Epub 2016 Jun 23. 


\section{Neurology}

\section{Teaching NeuroImages: Spontaneous regression of AVM feeding pedicle pseudoaneurysms \\ Enrico Giordan, Lorenzo Rinaldo and Giuseppe Lanzino \\ Neurology 2018;90;e1935-e1936 \\ DOI 10.1212/WNL.0000000000005565}

\section{This information is current as of May 21, 2018}

\section{Updated Information \& Services}

Subspecialty Collections

Permissions \& Licensing

Reprints including high resolution figures, can be found at: http://n.neurology.org/content/90/21/e1935.full

This article, along with others on similar topics, appears in the following collection(s):

All Cerebrovascular disease/Stroke

http://n.neurology.org/cgi/collection/all_cerebrovascular_disease_strok e

Arteriovenous malformation

http://n.neurology.org/cgi/collection/arteriovenous_malformation Intracerebral hemorrhage

http://n.neurology.org/cgi/collection/intracerebral_hemorrhage Other cerebrovascular disease/ Stroke

http://n.neurology.org/cgi/collection/other_cerebrovascular_disease_s troke

Information about reproducing this article in parts (figures,tables) or in its entirety can be found online at:

http://www.neurology.org/about/about_the_journal\#permissions

Information about ordering reprints can be found online:

http://n.neurology.org/subscribers/advertise

Neurology ${ }^{\circledR}$ is the official journal of the American Academy of Neurology. Published continuously since 1951, it is now a weekly with 48 issues per year. Copyright @ 2018 American Academy of Neurology. All rights reserved. Print ISSN: 0028-3878. Online ISSN: 1526-632X.

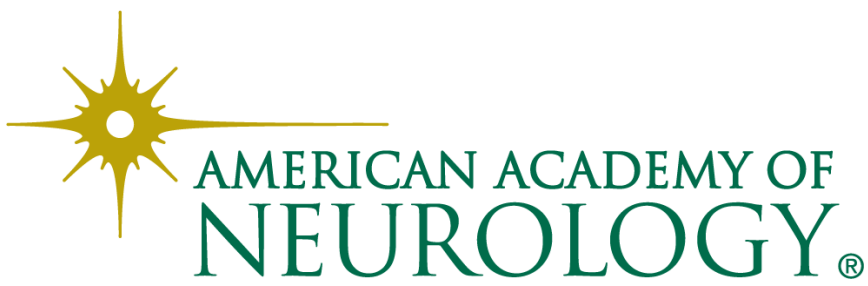

